\title{
Dukungan tenaga kesehatan dalam keberhasilan ASI eksklusif: A scoping review
}

\author{
Dyah Ayu Fitriani ${ }^{1 *}$, Andari Wuri Astuti ${ }^{2}$, Fitria Siswi Utami ${ }^{3}$ \\ 1,2,3 Universitas 'Aisyiyah Yogyakarta
}

\section{INFORMASI ARTIKEL:}

\begin{tabular}{l}
\hline Riwayat Artikel: \\
Tanggal diterima: 30 Juni 2021 \\
Tanggal direvisi: 26 Juli 2021 \\
Tanggal dipublikasi: 20 Agustus 2021 \\
\hline Kata kunci: \\
ASI Eksklusif \\
Dukungan Tenaga Kesehatan \\
Ibu
\end{tabular}

\subsection{6/jrki.v5i1.176}

Keyword:

Exclusive Breastfeeding

Mother

Support Health Professionals

\begin{abstract}
ABSTRAK
Latar belakang: Dua tahun pertama kehidupan manusia merupakan masa emas untuk membentuk fondasi pertumbuhan, perkembangan, dan kesehatan dalam jangka panjang, sehingga sangat penting untuk memastikan bahwa anak usia 0-2 tahun mendapatkan nutrisi yang optimal. Upaya yang lebih mudah dan lebih murah untuk mencapainya adalah dengan memberdayakan ibu dalam pemberian ASI Eksklusif dan terus memberikan ASI hingga 2 tahun, serta makanan pendamping yang berkualitas. Tujuan penelitian: Mereview evidence terkait dukungan tenaga kesehatan pada ibu dalam keberhasilan ASI Eksklusif. Metode: Scoping review ini menggunakan framework dari Arksey dan O'Malley. Hasil: Berdasarkan 8 artikel terseleksi, diperoleh 3 artikel dengan grade A dan 5 artikel dengan grade B, 1 artikel dari negara berkembang dan 7 artikel dari negara maju. Tiga tema muncul sebagai hasil dari scoping review yaitu jenis dukungan tenaga kesehatan, Respon ibu terhadap dukungan tenaga kesehatan, dan manfaat dukungan tenaga kesehatan dalam keberhasilan ASI Eksklusif. Simpulan: Dari 8 artikel yang ditelaah ditemukan bahwa dukungan tenaga kesehatan adalah salah satu faktor yang terkait dengan pemberian ASI Eksklusif pada ibu yang menyusui. Secara khusus, ibu yang menerima dukungan tenaga kesehatan yang memadai memiliki manfaat dalam meningkatkan kepercayaan diri dan kepuasan ibu serta dapat menambah wawasan dan pengetahuan ibu dalam ASI Eksklusif.
\end{abstract}

Background: The first two years of human life is golden period to form the foundation of growth, development, and health in long run. Therefore, it is important to ensure that children aged 0-2 years get optimal nutrition. Easier and more affordable effort to achieve it is by empowering mothers in the provision of exclusive breast milk and keep giving breast milk until 2 years, also side dishes with good quality. Objective: Research purpose to review the evidence related to professional health support to mother in the success of Exclusive breastfeeding. Methods: Method This scoping review uses Framework from Arksey and O'Malley. Results: 8 literatures have selected and included in Grade $A$ and Grade B. Three themes appear as result of scoping review which are types of professional health support, response of mother to professional health support, and advantages of professional health support in the success of Exclusive breastfeeding. Conclusion: From the 8 articles reviewed, it was found that the support of professional health is one of the factors related to exclusive breastfeeding in nursing mother. In particular, mother who receive sufficient professional health support have benefit in improving confidence and mother satisfaction also can add knowledge in Exclusive breastfeeding. memastikan bahwa anak usia 0-2 tahun

\section{Pendahuluan}

Dua tahun pertama awal kehidupan setelah manusia dilahirkan adalah masa emas untuk membentuk fondasi pertumbuhan, perkembangan, dan kesehatan dalam jangka

* Korespondensi penulis.

Alamat E-mail: fituri32@mail.com mendapatkan nutrisi yang optimal. Upaya yang lebih mudah dan murah untuk mencapainya adalah dengan memberdayakan ibu dalam pemberian ASI Eksklusif dan terus memberikan ASI hingga 2 tahun, serta makanan pendamping yang berkualitas (WHO, 2015).

Organisasi Kesehatan Dunia (WHO) merekomendasikan pemberian ASI Eksklusif selama 6 bulan pertama kehidupan, diikuti oleh 
pemberian ASI berkelanjutan dengan makanan pendamping yang sesuai hingga 2 tahun atau lebih (2). Resolusi Majelis Kesehatan Dunia (WHA 65) pada tahun 2012, mengesahkan rencana implementasi komprehensif pada nutrisi ibu, bayi dan anak, yang menetapkan enam target gizi global untuk tahun 2025, salah satunya adalah meningkatkan tingkat pemberian ASI Eksklusif dalam 6 bulan pertama hingga setidaknya 50\%.

Sebagian besar ibu di beberapa negara berhenti menyusui anaknya sebelum anak berusia 2 tahun. Banyak kendala yang muncul dalam upaya memberikan ASI eksklusif selama enam bulan pertama kehidupan bayi, faktor yang mempengaruhi diantaranya faktor sosial, budaya, ekonomi dan politik. Dalam beberapa penelitian yang telah dilakukan menunjukkan bahwa perilaku orang tua adalah pendukung kuat dalam pilihan pemberian makanan bayi. Orang tua yang memiliki sikap dan pengetahuan tentang manfaat kesehatan dan keunggulan ASI memiliki sikap yang lebih positif terhadap pemberian ASI daripada orang tua yang memberi bayi dengan susu formula, karena mereka lebih sadar akan manfaat kesehatan dan keunggulan gizi. Masalah lain dalam praktik pemberian ASI eksklusif adalah kurangnya pengetahuan ibu, dan mendukung lingkungan, penyediaan makanan dan minum terlalu dini, dan maraknya promosi susu formula bayi untuk bayi. Keterkaitan pada tahun 2002 melaporkan bahwa kepercayaan tradisional, pendidikan ibu dan sikap ibu terhadap pemberian ASI rendah, serta perbedaan di daerah perumahan menjadi kendala yang mempengaruhi keberlanjutan menyusui.

Tingkat pendidikan ibu, pekerjaan dan kelas antenatal juga berperan dalam keberhasilan pemberian ASI eksklusif. Informasi tentang keuntungan menyusui dan manajemen laktasi harus menjadi prioritas di kelas antenatal. Oleh karenanya tenaga kesehatan mempunyai peran penting untuk mendukung keberhasilan menyusui. Selain itu, keberhasilan ibu menyusui juga harus didukung oleh suaminya, keluarga, dan petugas kesehatan masyarakat. Promosi kesehatan menyusui selama manfaat antenatal akan mempengaruhi tingkat keberhasilan praktik menyusui. Upaya promosi melalui berbagai media tentang pentingnya ASI eksklusif masih terus dilakukan meskipun capaian program semakin meningkat.
Masalah ini perlu dilakukan intervensi untuk mengubah perilaku pada ibu menyusui eksklusif. Intervensi yang tepat adalah pendidikan atau promosi kesehatan, karena dengan metode ini walaupun membutuhkan waktu yang relatif lama, tetapi bentuknya adalah perubahan perilaku yang langgeng. Intervensi lain adalah intervensi pribadi, yaitu perencanaan dan persiapan prenatal, pembagian pekerjaan, dan penitipan anak. Untuk itu setiap wanita hamil dan keluarganya harus diberikan pendidikan kesehatan tentang pentingnya pemberian ASI eksklusif dan penatalaksanaannya selama kehamilan, nifas dan menyusui yang bisa diperoleh melalui edukasi dari tenaga kesehatan. Berdasarkan latar belakang diatas peneliti tertarik melakukan scoping review untuk melihat dukungan tenaga kesehatan dalam keberhasilan ASI Eksklusif saat ini.

\section{Metode penelitian}

Metode scoping review ini menggunakan framework Arksey dan O'malley (2005). Adapun tahapan yang dilakukan dalam Review scoping review terdiri dari: (1) Mengidentifikasi pertanyaan scoping review, (2) Mengidentifikasi artikel yang relevan, (3) Seleksi artikel, (4) Pemetaan Data (Data charting), (5) Menyusun, meringkas dan melaporkan hasil (Arksey \& O'Malley., 2005).

\section{Identifikasi Pertanyaan Scoping review}

Perumusan pertanyaan penelitian ini menggunakan framework model PICO (Population, Intervention, Comparison, dan Outcome) dalam mengelola dan memecahkan fokus review. PICO adalah format untuk mengembangkan pertanyaan penelitian klinis yang baik sebelum seseorang memulai penelitian. Menggunakan PICO akan membantu dalam mengklarifikasi pertanyaan, dan membantu menentukan konsep pencarian dan jenis studi yang paling tepat untuk menjawab pertanyaan penelitian (EBSCO health, 2018). Berdasarkan framework tersebut pertanyaan penelitian ini adalah "Bagaimana dukungan tenaga kesehatan pada ibu dalam keberhasilan ASI Eksklusif?" framework PICO Disajikan pada tabel 1. 


\begin{tabular}{llcl}
\multicolumn{3}{c}{ Tabel 1. } & Framework Criteria of Inclusion and Exclusion \\
\hline Population & Intervention & Comparation & Outcomes \\
\hline Mother & Support & - & Outcomes, \\
Women & health & problem, \\
Breastfeeding & professionals, & consequence, \\
mother & Support of & effect impact, \\
& health & experience \\
& workers & \\
\end{tabular}

\section{Identifikasi artikel yang relevan}

Langkah kedua adalah mengidentifikasi artikel yang relevan. Dalam pemilihan artikel yang relevan terdapat 3 Data based yang digunakan dalam pencarian artikel diantaranya, yaitu Pubmed, Science Direct, dan Wiley. Hasil studi literatur dari 3 data based tersebut, kemudian dilakukan screening judul menyeluruh dari data based tersebut menggunakan keyword teridentifikasi. Keyword yang akan digunakan dalam pencarian literature, keyword yang didesain dan difokuskan pada framework diperluas dengan menentukan sinonim melalui Thesurus dan Booleant sehingga keyword yang digunakan dalam scoping review ini yaitu Mother OR Mother's OR Women OR Women's OR "Breastfeeding Mother" AND "Support Health Professionals" OR "Support of Health workers" AND Outcomes OR Problem OR Consequence OR Effect OR Impact OR Experience. Dalam seleksi artikel yang relevan, peneliti memilih kriteria inklusi dan eksklusi yang akan digunakan sebagai sumber scoping review ini. Berikut adalah kriteria inklusi dan eksklusi:

Tabel 2. Framework Criteria of Inclusion and Exclusion

\begin{tabular}{lll}
\hline \multicolumn{1}{c}{ Kriteria Inklusi } & \multicolumn{1}{c}{ Kriteria eksklusi } \\
\hline 1. Articles Publish between & 1. & Opinion article \\
$2009-2019$ & Report articles, \\
2. Article published in English & literature review \\
3. Primary research or & & \\
$\begin{array}{l}\text { published in peer reviewed } \\
\text { Journal }\end{array}$ & \\
\hline
\end{tabular}

\section{Seleksi artikel}

Dalam pencarian artikel dari semua database yang diakses teridentifikasi awal 1.711 artikel yang relevan dengan pertanyaan scoping review. Artikel tersebut selanjutnya dieliminasi mulai dari screening judul dan abstrak dan diperoleh 62 artikel. Kemudian artikel dieliminasi kembali setelah full text-reading didapatkan 8 artikel untuk diambil dan ditinjau secara independen berdasarkan kriteria inklusi dan eksklusi yang telah ditentukan. Dalam proses seleksi artikel ini peneliti menggunakan PRISMA
Flowchart untuk mendeskripsikan secara transparan proses yang sudah dilakukan. PRISMA Flowchart adalah serangkaian item minimum berbasis bukti untuk pelaporan dalam systematic review dan meta-analysis, PRISMA Flowchart dinilai tepat digunakan karena penggunaannya dapat meningkatkan kualitas pelaporan publikasi (PRISMA, no date; Liberati et al, 2009; Mother et al, 2009; Peters et al, 2015).

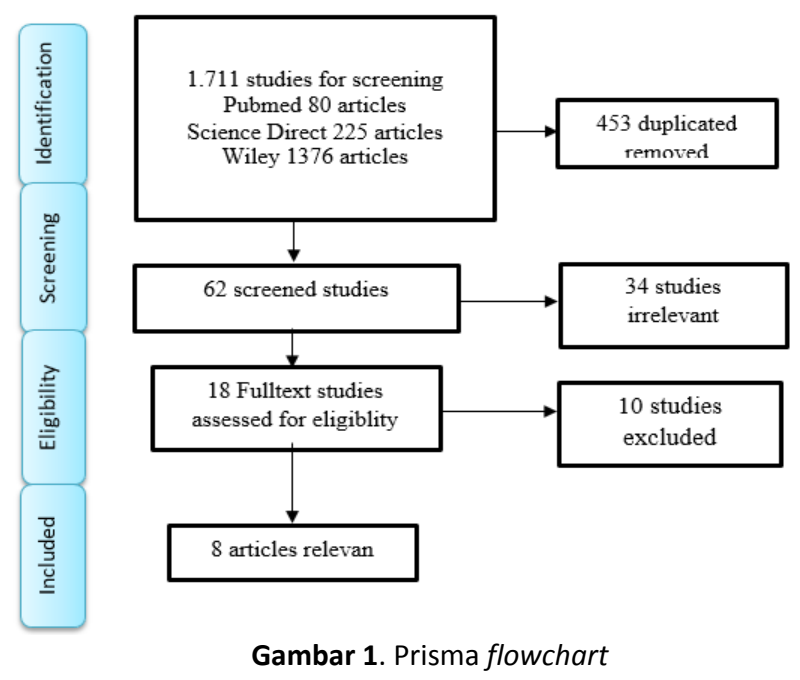

Setelah melakukan pemilihan studi, untuk mengetahui kualitas artikel yang telah dipilih, maka dilakukan Critical appraisal untuk menilai kualitas artikel yang akan digunakan. Alat yang dipilih untuk menilai kualitas artikel dalam scoping review ini yaitu menggunakan The Joanna Briggs Institute (JBI) Critical appraisal Tools. Pada tahap Critical Appraisal terdapat 8 artikel yang sesuai dengan topik dan kriteria inklusi yang sudah ditetapkan oleh penulis, study design yang digunakan meliputi qualitative, cross sectional, dan cohort. Masing-masing metode penelitian memiliki cekclist Critical Appraisal yang berbedabeda. Untuk menilai kualitas 8 artikel yang masuk pada tahap Critical Appraisal penulis menggunakan skala grade A, B, dan C untuk membedakan kategori artikel yang masuk dalam kategori Baik (Grade A), Cukup Baik (Grade B), Kurang Baik (Grade C). 


\section{Charting data}

Table 3. Charting data

\begin{tabular}{|c|c|c|c|c|}
\hline No. & $\begin{array}{c}\text { Judul / Penulis / } \\
\text { Tahun/Grade/Negara }\end{array}$ & Aims & $\begin{array}{l}\text { StudiDesain } \\
\text { Metode/ } \\
\text { Sampel } \\
\end{array}$ & Hasil \\
\hline 1 & $\begin{array}{l}\text { Nurses and midwives } \\
\text { professional support } \\
\text { increases with } \\
\text { improved attitudes - } \\
\text { design and effects of } \\
\text { a longitudinal } \\
\text { randomized } \\
\text { controlled process- } \\
\text { oriented } \\
\text { intervention/Anette } \\
\text { C Ekstrom, et } \\
\text { al/2015/A/Swedia }\end{array}$ & $\begin{array}{l}\text { Untuk } \\
\text { menggambarkan } \\
\text { pendekatan } \\
\text { metodologis } \\
\text { untuk } \\
\text { meningkatkan dan } \\
\text { mengevaluasi } \\
\text { sikap profesional } \\
\text { perawatan } \\
\text { kesehatan } \\
\text { terhadap } \\
\text { menyusui dan } \\
\text { dukungan orang } \\
\text { tua untuk } \\
\text { meningkatkan } \\
\text { kualitas } \\
\text { perawatan dalam } \\
\text { melahirkan anak. }\end{array}$ & $\begin{array}{l}\mathrm{RCT} / \\
\text { random } \\
\text { sampling/ } \\
565 \mathrm{ibu} \\
\text { postpartum }\end{array}$ & $\begin{array}{l}\text { Hasil pelatihan berorientasi proses } \\
\text { meningkatkan sikap profesional } \\
\text { terhadap menyusui dan dukungan } \\
\text { orang tua. Peningkatan sikap dalam } \\
\text { profesional kesehatan ini } \\
\text { meningkatkan intervensi-kelompok ibu } \\
\text { kepuasan dengan dukungan } \\
\text { profesional dan sosial. Hubungan ibu } \\
\text { dengan intervensi-kelompok dan } \\
\text { perasaan untuk bayi mereka serta } \\
\text { menyusui juga ditingkatkan. }\end{array}$ \\
\hline 2 & $\begin{array}{l}\text { Professional } \\
\text { breastfeeding } \\
\text { support for first-time } \\
\text { mothers: a } \\
\text { multicentre cluster } \\
\text { randomised } \\
\text { controlled trial/ ICY } \\
\text { Fu, et al./. 2014/ A } \\
\text { China }\end{array}$ & $\begin{array}{l}\text { Tujuan dari } \\
\text { penelitian ini } \\
\text { adalah untuk } \\
\text { menguji } \\
\text { keefektifan dari } \\
\text { dua intervensi } \\
\text { dukungan } \\
\text { pascakelahiran } \\
\text { dini yang } \\
\text { diberikan kepada } \\
\text { ibu pertama kali } \\
\text { oleh profesional } \\
\text { perawatan } \\
\text { kesehatan terlatih } \\
\text { tentang hasil } \\
\text { menyusui. } \\
\end{array}$ & $\begin{array}{l}\text { RCT/ a } \\
\text { multicentre } \\
\text { cluster } \\
\text { randomised } \\
\text { controlled } \\
\text { trial/ } 724 \mathrm{ibu} \\
\text { menyusui }\end{array}$ & $\begin{array}{l}\text { Angka dari setiap dan menyusui } \\
\text { eksklusif lebih tinggi di antara peserta } \\
\text { dalam dua kelompok intervensi sama } \\
\text { sekali tindak lanjut poin, jika } \\
\text { dibandingkan dengan mereka yang } \\
\text { menerima perawatan standar. Peserta } \\
\text { yang menerima dukungan telepon jauh } \\
\text { lebih banyak kemungkinan untuk } \\
\text { melanjutkan menyusui pada 1 } \\
\text { bulan. Peserta dalam kelompok } \\
\text { pendukung rumah sakit juga lebih } \\
\text { cenderung menyusui di semua titik } \\
\text { wakktu, tetapi efeknya tidak signifikan } \\
\text { secara statistik. }\end{array}$ \\
\hline 3 & $\begin{array}{l}\text { "the right help at the } \\
\text { right time": positive } \\
\text { constructions of peer } \\
\text { and professional } \\
\text { support for } \\
\text { breastfeding/ Elaine } \\
\text { Burns, et al/ 2017/ } \\
\text { B/Australia }\end{array}$ & $\begin{array}{l}\text { Tujuan dari } \\
\text { penelitian ini } \\
\text { adalah untuk } \\
\text { mengetahui } \\
\text { kesamaan dan } \\
\text { perbedaan gaya } \\
\text { komunikasi } \\
\text { menyusui, dan } \\
\text { bahasa serta } \\
\text { praktik yang } \\
\text { digunakan, pada } \\
\text { bulan pertama } \\
\text { setelah } \\
\text { melahirkan, oleh } \\
\text { bidan praktik } \\
\text { swasta (PPM), } \\
\text { bekerja dalam } \\
\text { model perawatan } \\
\text { kontinuitas, dan, } \\
\text { konselor dar. } \\
\text { dukungan sebaya } \\
\text { (PSC) menyusui } \\
\text { yang terlatih } \\
\text { memberikan } \\
\text { dukungan di } \\
\text { ruang tunggu } \\
\text { berbasis } \\
\text { komunitas } \\
\text { organisasi } \\
\text { menyusui } \\
\text { nasional. }\end{array}$ & $\begin{array}{l}\text { kualitatiff } \\
\text { wawancara } \\
22 \quad \text { ibu } \\
\text { menyusui }\end{array}$ & 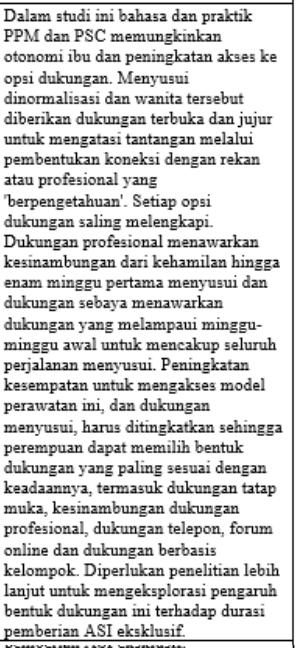 \\
\hline 4 & $\begin{array}{l}\text { Two sides of } \\
\text { breastfeeding } \\
\text { support: experiences } \\
\text { of women and } \\
\text { midwives /Caroline, } \\
\text { et all/2010/B } \\
\text { Swedia }\end{array}$ & \begin{tabular}{l|} 
Penelitian ini \\
bertujuan untuk \\
menyelidiki \\
pengalaman dan \\
refleksi wanita \\
dalam menerima \\
dukungan \\
menyusui dan \\
pengalaman bidan \\
serta refleksi \\
dalam \\
memberikan \\
dukungan \\
menyusui.
\end{tabular} & \begin{tabular}{l|} 
Qualitative/ \\
Wawancara/ \\
Ibu dan \\
bidan yang \\
berpengalam \\
an dalam \\
mendukung \\
ASI \\
Ekskluisf di \\
county \\
selatan-barat \\
sivedia
\end{tabular} & $\begin{array}{l}\text { Pengalaman dan refleksi ibu dan bidan } \\
\text { dalam menerima dan memberikan } \\
\text { dukungan menyusui } \\
\text { dikonseptaliasasikan sebagai satu tema } \\
\text { utama: "Dukungan menyusui secara } \\
\text { individual meningkatkan kepercayaan } \\
\text { diri dan kepuasan." Tema ini berisi tiga } \\
\text { kategori: "Wanita unik", " "roses } \\
\text { konfirmasi yang sensitif", dan } \\
\text { "Konsistensi dukungan yang } \\
\text { berkelanjutan." "Untuk merasa percaya } \\
\text { diri dengan peran baru mereka sebagai } \\
\text { ibu, para wanita menginginkan lebih } \\
\text { banyak konfirmasi sebagai individu } \\
\text { yang unik dan sebagai wanita } \\
\text { menyusui; mereka ingin didengarkan; } \\
\text { dan mereka menginginkan lebih } \\
\text { banyak waktu, pengertian, dan tindak } \\
\text { lanjut dari para profesional kesehatan. } \\
\text { Sebaliknya, bidan menggambarkan diri } \\
\text { mereka sebagai pemberi semangat dan } \\
\text { penegasan akan kebutuhan wanita. }\end{array}$ \\
\hline
\end{tabular}

\begin{tabular}{|c|c|c|c|c|}
\hline 5 & $\begin{array}{l}\text { First-Time Mothers } \\
\text { Have a Desire to Be } \\
\text { Offered Professional } \\
\text { Breastfeeding } \\
\text { Support by Pediatric } \\
\text { Nurses: An } \\
\text { Evaluation of the } \\
\text { Mother-Perceived- } \\
\text { Professional Support } \\
\text { Scale } \text { Matilda } \\
\text { Möller Ranch, et al. } \\
\text { 2019/B/ Swedia }\end{array}$ & $\begin{array}{l}\text { Tujuan dari } \\
\text { penelitian ini } \\
\text { adalah untuk } \\
\text { mengeksplorasi } \\
\text { pengalaman ibu } \\
\text { pertama kali } \\
\text { dalam } \\
\text { memberikan } \\
\text { dukungan } \\
\text { menyusui yang } \\
\text { ditawarkan oleh } \\
\text { perawat pediatrik, } \\
\text { serta untuk } \\
\text { mengembangkan } \\
\text { dan mengevaluasi } \\
\text { skala Mother } \\
\text { Perceived Support } \\
\text { from } \\
\text { Professionals } \\
\text { (MoPPS). }\end{array}$ & \begin{tabular}{|l|} 
Qualitative/ \\
Wawancaral \\
9 ibu primi \\
postpartum
\end{tabular} & 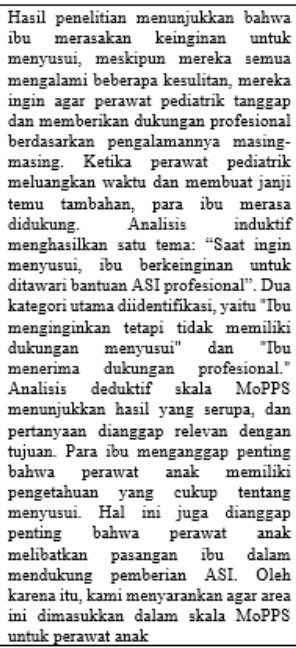 \\
\hline 6 & $\begin{array}{l}\text { The supporting role } \\
\text { of the midwife } \\
\text { during the first } 14 \\
\text { days of } \\
\text { breastfeeding: A } \\
\text { descriptive } \\
\text { qualitative study in } \\
\text { maternity wards and } \\
\text { primary healthcare/ } \\
\text { Marlies, et al./ } \\
\text { 2019/ A/Belgia }\end{array}$ & $\begin{array}{l}\text { Tujuan umum dari } \\
\text { penelitian ini } \\
\text { adalah untuk } \\
\text { mendapatkan } \\
\text { pemahamanan yang } \\
\text { mendalam tentang } \\
\text { peran pendukung } \\
\text { bidan dalam } \\
\text { mendukung } \\
\text { pemberian ASI } \\
\text { selama dua minggu } \\
\text { pertama setelah } \\
\text { melahirkan dan } \\
\text { membandingkanny } \\
\text { a dengan } \\
\text { kebutuhan ibu } \\
\text { menyusui. }\end{array}$ & \begin{tabular}{|c} 
Qualitative/ \\
Wawancara \\
Bidan 10 dan \\
$9 \mathrm{Ibu}$ \\
menyusui
\end{tabular} & 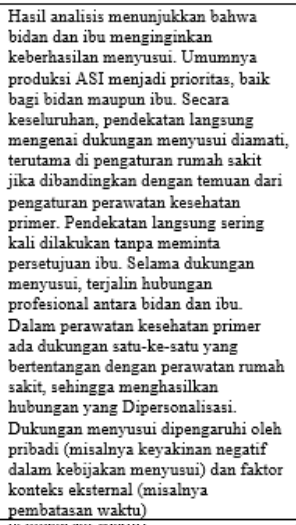 \\
\hline 7 & $\begin{array}{l}\text { The Association } \\
\text { Between Women's } \\
\text { Perceptions of } \\
\text { Professional Support } \\
\text { and Problems } \\
\text { Experienced on } \\
\text { Breastfeeding } \\
\text { Cessation: A Western } \\
\text { Australian Study/ } \\
\text { Yvonne L, et al./ } \\
\text { 2010/B/Australia }\end{array}$ & \begin{tabular}{|l|} 
untuk \\
menentukan \\
hubungan antara \\
masalah \\
menyusui wanita, \\
persepsi mereka \\
tentang dukungan \\
dari bidan dan \\
perawat kesehatan \\
anak, dan \\
penghentian \\
menyusui dalam \\
10 minggu \\
pertama setelah \\
melahirkan dalam \\
sampel wanita \\
Australia Barat \\
\end{tabular} & \begin{tabular}{|l|} 
A cross- \\
sectional \\
survey// \\
kuesioner// \\
2669 bu \\
primipara
\end{tabular} & 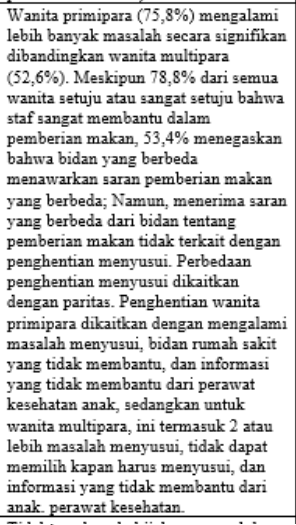 \\
\hline 8 & 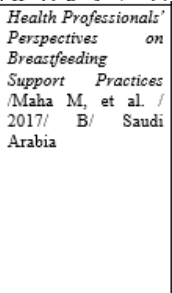 & \begin{tabular}{|l|} 
Penelitian ini \\
dilakukan untuk \\
menilai perspektif \\
dan pendapat \\
tenaga kesehatan \\
tentang praktik \\
dukungan \\
menyusui di \\
rumah sakit \\
pendidikan. \\
\end{tabular} & \begin{tabular}{|l|} 
cross - section \\
al study/ \\
kuesioner/ \\
28 staf medis
\end{tabular} & $\begin{array}{l}\text { Tidak ada kebijakan pendukung } \\
\text { menyusui yang diikuti di rumah sakit } \\
\text { seperti yang direkomendasikan oleh } \\
\text { BFHI. bu dengan masalah menyusui } \\
\text { tidak dirujuk untuk mendapatkan } \\
\text { bantuan dan tindak lanjut panggilan } \\
\text { telepon tidak dilakukan kepada wanita } \\
\text { nifas getelah keluar dari rumah sakit. } \\
\text { Profesional perawatan kesehatan } \\
\text { menunjukkan bahwa tidak ada } \\
\text { kelompok pendukung menyusui } \\
\text { berbasis rumah gakit, konsultan } \\
\text { spesialis laktasi atau unit manajemen } \\
\text { laktasi yang tersedia. }\end{array}$ \\
\hline
\end{tabular}




\section{Menyusun, meringkas dan melaporkan hasil}

Sama halnya dengan yang dilakukan (Levac, Colquhoun and O'Brien, 2010), penulis melakukan pendekatan tiga fase untuk menyusun, meringkas, dan melaporkan hasil. Pertama, analisis numerik deskriptif disediakan yang mencakup karakteristik artikel. Kedua, kekuatan dan kelemahan dalam literatur yang diidentifikasi melalui analisis tematik dari studi yang disertakan dalam laporan. Fase akhir tahap ini adalah peninjauan implikasi temuan dalam kaitannya dengan penelitian, praktik dan kebijakan dimasa depan.

\section{Hasil dan Pembahasan}

Berdasarkan 8 artikel yang telah terpilih, selanjutnya dilakukan charting data untuk menggolongkan beberapa poin atau bagian dari artikel seperti tujuan penelitian, desain penelitian, jumlah sampel, dan hasil atau temuan dari penelitian tersebut. Sejumlah 8 artikel yang terpilih menggunakan desain penelitian qualitative study sebanyak 4 artikel, RCT Study sebanyak 2 artikel, dan cross sectional study sebanyak 2 artikel. Semua artikel ini berasal dari Negara Maju dan Berkembang. Setelah dianalisis dan dievaluasi dari beberapa point diatas maka hasil pengumpulan dari ekstraksi data sesuai dengan judul Scoping review, maka diperoleh hasil sebagai berikut:

\section{Karakteristik artikel berdasarkan negara}

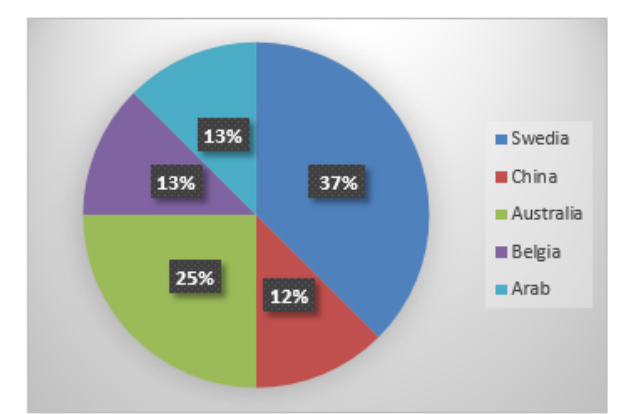

Gambar 2. Karakteristik berdasarkan negara

Dari 8 artikel yang sesuai dan berkualitas baik, berdasarkan kriteria inklusi yang dibuat semua artikel yang dipilih berasal dari negara berkembang. Artikel tersebut kemudian dikelompokkan sesuai dengan Negara.

\section{Karakteristik artikel berdasarkan metode}

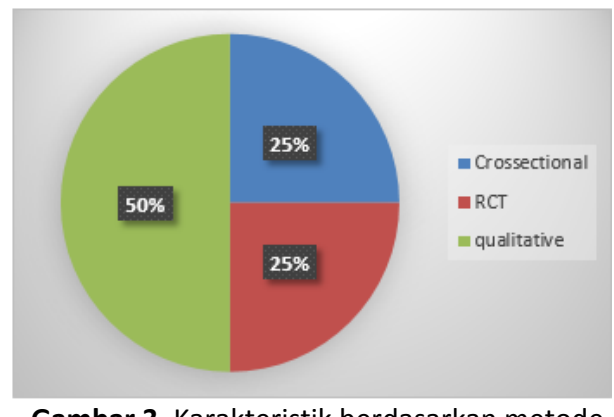

Gambar 3. Karakteristik berdasarkan metode

Dari 8 artikel yang dipilih, artikel tersebut kemudian dikelompokkan berdasarkan metode penelitian yang digunakan.

\section{Karakteristik artikel berdasarkan grade}

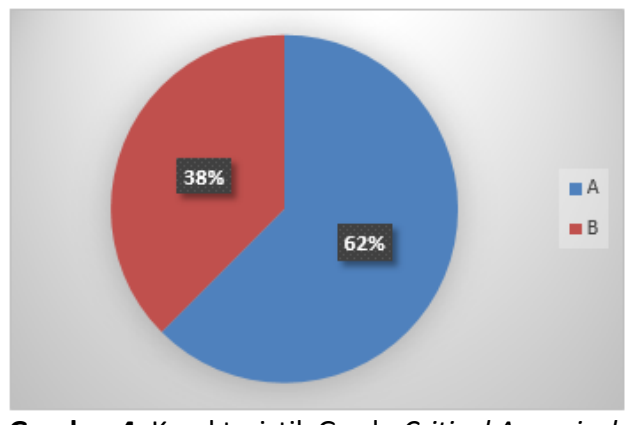

Gambar 4. Karakteristik Grade Critical Appraisal

Artikel yang dipilih dilakukan critical appraisal menggunakan Joana Brigs Institute (JBI) untuk menilai kualitas dari artikel, maka dari 8 artikel tersebut kemudian dikelompokkan berdasarkan metode penelitian yang digunakan.

\section{Tema}

Dalam scoping review didapatkan hasil temuan tema. Disajikan pada gambar 4 .

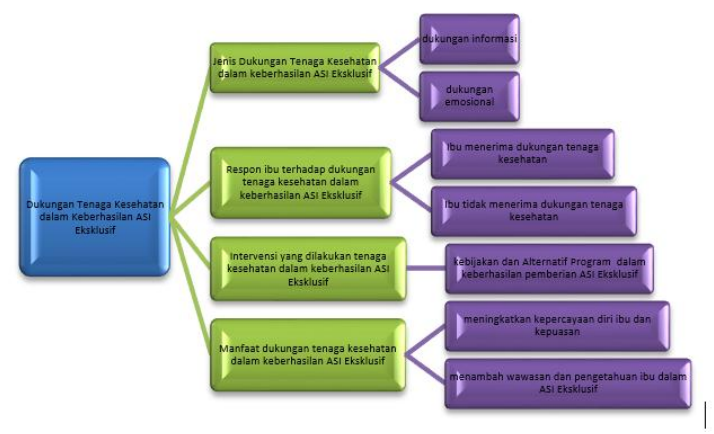

Gambar 5. Mapping theme 


\section{Pembahasan}

\section{Jenis Dukungan tenaga kesehatan dalam keberhasilan pemberian ASI Eksklusif}

\section{a. Dukungan Informasi}

Mendukung wanita untuk menyusui secara eksklusif merupakan suatu strategi yang penting dalam kesehatan masyarakat. Namun, menyusui adalah salah satu dari beberapa perilaku peningkatan kesehatan yang lebih umum di negara-negara berkembang daripada di negara Maju. Diketahui bahwa perempuan dari negaranegara berpenghasilan tinggi, sejak mingguminggu awal menyusui sangat kesulitan untuk menyusui anaknya sehingga membutuhkan dukungan dalam keberhasilan ASI Eksklusif. Berdasarkan review penelitian dari 8 artikel, 7 diantaranya menjelaskan tentang pentingnya dukungan informasi ASI Eksklusif pada ibu yang menyusui bayinya, yaitu $A 1, A 2, A 3, A 4, A 5, A 6$, dan A7. Hasil penelitian ini menunjukkan bahwa pentingnya ibu menerima dukungan menyusui melalui pemberian informasi bermanfaat untuk keberhasilan pemberian ASI Eksklusif. Namun, kualitas yang diberikan oleh tenaga kesehatan dan kualitas informasi yang dinilai positiflah yang akan membuat ibu merasa nyaman, percaya, dan terbuka. Sehingga, pentingnya tenaga kesehatan informasi untuk memberikan informasi yang baik dan bermanfaat (Yvonne, et al. 2011).

Ketika para ibu merasa kurangnya dukungan dari profesional atau tenaga kesehatan, mereka merasa perlu untuk mencari dukungan di tempat lain, apakah baik itu dari sebuah klinik khusus menyusui, dukungan sosial, atau informasi di internet. Tenaga kesehatan yang memberikan saran atau informasi terkadang kontradiksi dan tidak membantu, atau ketika tampaknya ibu merasa tidak didengarkan, para ibu merasa seperti dukungan menyusui yang diberikan tidak cukup. Para ibu mengungkapkan pengalaman mereka bahwa terkadang tenaga kesehatan yang ada waktu dipelayanan lebih fokus dalam memberi tindakan dan tidak memberikan tambahan informasi terkait menyusui yang baik dan benar untuk menunjang keberhasilan dalam pemberian ASI Eksklusif (Ranch, et al. 2019).

Dukungan informasi dari tenaga kesehatan dengan cara pendekatan pada ibu menyusui sangatlah penting. Dengan pemberian konseling membuat ibu bisa lebih mengerti dan paham.
Selain itu dengan pendekatan ibu bisa terbuka dan merasa nyaman (Elaine, et al. 2017).

\section{b. Dukungan Emosional}

Menyusui adalah proses alami yang membutuhkan pengajaran dan pembelajaran sehingga tenaga kesehatan penting untuk menyediakan dukungan informasi dan emosional diawal pasca melahirkan (ICY Fu, et al. 2014). Selain itu, diketahui bahwa perempuan dari negara-negara berpenghasilan tinggi, sejak awal minggu persalinan sangat sulit untuk menyusui sehingga membutuhkan dukungan emosional dan praktis dari orang lain atau tenaga kesehatan (Elaine, et al. 2017). Berdasarkan review penelitian dari 8 artikel, semua menjelaskan tentang pentingnya dukungan emosional pada ibu yang menyusui bayinya, yaitu $A 1, A 2, A 3, A 4, A 5, A 6, A 7$, dan A8 dalam keberhasilan pemberian ASI Eksklusif. Sikap Seorang tenaga kesehatan mempengaruhi persepsi seorang ibu tentang dukungan menyusui. Dukungan emosional penting untuk kepuasan ibu yang menyusui.

Dukungan emosional perlu untuk dilakukan oleh setiap tenaga kesehatan pada pasien khususnya ibu menyusui karena dengan memberikan dukungan emosional dapat meningkatkan rasa kepercayaan dan kepuasan ibu terhadap tenaga kesehatan karena setiap ibu ingin dilihat sebagai individu yang unik oleh para tenaga kesehatan, dan mereka juga ingin para tenaga kesehatan untuk menilai bagaimana cara menyusui mereka sudah sesuai atau belum (Caroline, et al. 2010).

\section{Respon ibu terhadap Dukungan tenaga kesehatan dalam keberhasilan pemberian Asi Ekslusif}

\section{a. Ibu menerima dukungan tenaga kesehatan}

Hasil jurnal penelitian (Edwards et al., 2017) menyatakan Menyusui secara eksklusif selama 6 bulan memberikan jangka pendek dan jangka panjang yang bermanfaat bagi bayi dan ibu. Hal ini terkait untuk mengurangi risiko morbiditas dan mortalitas pada bayi, dan untuk meningkatkan kesehatan ibu. Hasil penelitian dapat diketahui bahwa terdapat peningkatan efek sikap ibu menyusui dari dukungan tenaga kesehatan terkait keberhasilan dalam pemberian ASI Eksklusif, diantaranya banyak ibu yang memberikan persepsi positif dari dukungan tenaga kesehatan atau 
profesional. Ibu melaporkan dukungan tenaga kesehatan lebih berpengaruh dari dukungan orang tua, mertua, dan pasangan. Ibu melaporkan terdapat peningkatan dukungan untuk menyusui secara eksklusif selama 6 bulan tanpa tambahan apapun sehingga ibu merasakan ada ikatan yang lebih kuat antara ibu dan bayinya ketika menyusui, serta meningkatnya frekuensi menyusui lebih tinggi (Anette, et al. 2015).

Peningkatan sikap dalam profesi kesehatan membuat para ibu lebih puas dengan tenaga kesehatan. Selain itu, peningkatan profesional tenaga kesehatan mendukung peningkatan perasaan dan hubungan ibu dengan bayi, inisiasi sebelumnya, dan frekuensi menyusui yang lebih tinggi selama 24 jam, dan lebih lama durasi menyusuinya. Hal ini diperkuat dengan sebuah cochrane review dari Asosiasi antara dukungan yang diberikan oleh para profesional atau tenaga kesehatan dan durasi menyusui menunjukkan bahwa dukungan profesional tambahan yaitu efektif dalam memperpanjang durasi setiap menyusui, tetapi efek dari dukungan profesional tambahan pada ASI Eksklusif masih kurang jelas (Caroline, et al. 2010).

\section{b. Ibu tidak menerima Dukungan Tenaga Kesehatan}

Dukungan tenaga kesehatan sangat berpengaruh dalam keberhasilan pemberian ASI Eksklusif pada bayi. Berdasarkan review artikel yang dilakukan terdapat 3 artikel yang menjelaskan mengapa ibu tidak menerima dukungan dari tenaga kesehatan dikarenakan beberapa faktor, diantaranya: tenaga kesehatan tidak memberikan informasi tentang kebutuhan bayi selama menyusui, tidak menjelaskan persiapan untuk peran menjadi orang tua atau seorang ibu, sikap tenaga kesehatan yang tidak ramah dan memahami sehingga ibu merasa tidak nyaman, serta tidak memberikan cukup informasi tentang ASI Eksklusif (Ranch, et al. 2019).

Pada artikel Ranch, et al (2019) ibu-ibu menyatakan bahwa tenaga kesehatan harus lebih memahami kebutuhan mereka untuk dukungan profesional dalam keberhasilan ASI Eksklusif. Tenaga kesehatan diharapkan agar menempatkan usaha ekstra dalam mendukung ibu yang pertama kali menyusui bayinya, karena mereka tidak memiliki pengalaman sebelumnya. Perasaan ketidakpastian mengenai menyusui dan tidak mengetahui apa yang harus dilakukan membuat ibu merasa frustasi serta kecewa. Ketika para ibu merasa bahwa dukungan yang mereka terima dari tenaga kesehatan itu tidak cukup, mereka mencoba untuk menemukan bantuan dari berbagai sumber yang bisa mereka dapatkan. Dukungan sosial juga berperan penting dalam kelanjutan menyusui, sehingga para ibu beralih mencari informasi ke internet.

Ketika ibu merasa bahwa mereka tidak memiliki dukungan profesional dari tenaga kesehatan, mereka sering berbicara tentang pertemuan perawat yang berbeda dan menerima saran yang bertentangan atau tidak membantu menurut mereka ke orang lain. Mereka merasa bahwa lingkungan perawat kesehatan tidak mendorong mereka untuk bertanya tentang menyusui, sehingga mereka berhenti meminta bantuan. Beberapa dari mereka tidak percaya saran yang diberikan oleh tenaga kesehatan. Beberapa bahkan takut proses menyusui mereka akan terhambat jika mereka mengikuti saran perawat kesehatan (Caroline, et al. 2010).

Dua penelitian mengungkapkan tekanan psikologis pada ibu muda primipara. Ibu muda merasa tertekan karena merasa tidak siap menghadapi kehamilan (Roberts et al., 2011) dan tujuh dari 30 (23\%) ibu muda dilaporkan mengalami depresi dan 6,6\% percobaan bunuh diri (Wilson-mitchell et al., 2014). Perasaan ini terjadi pada ibu yang mengalami kehamilan yang tidak diinginkan dan kesulitan menerima tanggung jawab menjadi ibu (Mangeli et al., 2017).

Beberapa penelitian mengungkapkan perasaan negatif pada ibu muda terkait transisi menjadi ibu. Mereka juga menemukan sebagian besar ibu muda mengungkapkan perasaan positif yang terkait dengan tarnsisi menjadi ibu

\section{Respon ibu terhadap Dukungan tenaga kesehatan dalam keberhasilan pemberian Asi Ekslusif}

\section{a. Kebijakan Alternatif Program dalam Keberhasilan Pemberian ASI Eksklusif}

Kebijakan dalam meningkatkan pemberian ASI Eksklusif telah banyak dilakukan oleh berbagai negara. Berbagai upaya dilakukan untuk meningkatkan kesadaran betapa pentingnya pemberian ASI Eksklusif selama minimal 6 bulan pertama tanpa tambahan makanan apapun. Berdasarkan dari analisa scoping review yang telah dilakukan diketahui dari ke 8 artikel memiliki 
intervensi terhadap ibu postpartum untuk meningkatkan pemberian ASI Eksklusif melalui dukungan yang dilakukan oleh tenaga kesehatan. Kebijakan yang dilakukan oleh tenaga kesehatan untuk meningkatkan keberhasilan pemberian ASI Eksklusif diantaranya:

1) Mengikuti pelatihan yang berorientasi pada bidan dan perawat anak tentang menyusui dan dukungan orang tua (Anette., 2015).

2) Perawatan bersalin yang diberikan tenaga kesehatan harus sesuai standar perawatan postnatal di rumah sakit, meliputi perawatan perinatal rutin pada setiap pasien; konseling menyusui dilakukan oleh bidan, perawat, atau konselor laktasi; dan perawatan tambahan berupa konseling melalui telepon menyusui mingguan dengan durasi mulai dari 20-30 menit selama 4 minggu (ICYFu et al., 2014).

3) Mengikuti pelatihan konselor laktasi sebagai upaya untuk menambah kemampuan dalam meningkatkan keberhasilan menyusui yang baik dan benar.

\section{Respon ibu terhadap Dukungan tenaga kesehatan dalam keberhasilan pemberian Asi Ekslusif}

\section{a. Manfaat dukungan tenaga kesehatan dalam keberhasilan pemberian ASI Eksklusif}

Berdasarkan hasil review diketahui bahwa dukungan tenaga kesehatan sangat berperan penting dalam keberhasilan ASI Eksklusif pada ibu. Menyusui secara ekskluif direkomendasikan sebagai sumber nutrisi terbaik untuk bayi dan merupakan masalah kesehatan masyarakat yang penting (Caroline et al., 2010).

Tenaga kesehatan selaku provider memiliki peran penting dalam mencegah terjadinya komplikasi pada ibu dan bayi. Ibu yang baru memiliki anak pertama membutuhkan bantuan dan kepastian terlepas dari apakah ini anak pertama atau selanjutnya, memperkuat kebutuhan akan dukungan, informasi tentang menyusui, dan pendidikan tentang perawatan neonatal, hal ini erat kaitannya dengan kualitas pelayanan. Kualitas pelayanan dapat ditingkatkan dengan meningkatkan sumber daya manusia yang tersedia dan tanpa investasi besar. Peningkatan ini dapat mengurangi mortalitas dan morbiditas ibu dan bayi. (Marlies et al, 2019).
Selain itu, menyusui memberikan manfaat kesehatan yang signifikan bagi para ibu, bayi, dan keluarga, dan manfaat ekonomi secara substansial untuk masyarakat. Menurut seri Lancet (2014) menjelaskan bahwa menyusui, yaitu "ASI menjadikan dunia lebih sehat, anak lebih pintar, dan masih banyak lagi manfaat yang lain". Berdasarkan dari 8 artikel diperoleh hasil terdapat 5 artikel, yaitu A1, A2, A4, A6, A7 yang menjelaskan bahwa manfaat dukungan tenaga kesehatan dalam keberhasilan ASI Eksklusif, yaitu dapat meningkatkan kepercayaan diri dan kepuasan ibu dalam menyusui. Hal ini, dilihat dari dukungan informasi dari tenaga kesehatan dengan cara pendekatan pada ibu menyusui membuat ibu bisa lebih mengerti dan paham sehingga ibu bisa lebih terbuka, percaya diri dan merasa nyaman (Elaine, et al. 2017).

Dukungan emosional yang dilakukan oleh setiap tenaga kesehatan pada pasien khususnya ibu juga meningkatkan rasa kepercayaan dan kepuasan ibu terhadap tenaga kesehatan karena setiap ibu ingin dilihat sebagai individu yang unik oleh para tenaga kesehatan, dan mereka juga ingin para tenaga kesehatan untuk menilai bagaimana cara menyusui mereka sudah sesuai atau belum (Caroline, et al. 2010).

\section{b. Menambah wawasan dan pengetahuan ibu dalam keberhasilan ASI Eksklusif}

Berdasarkan penelitian ini diketahui bahwa selain memiliki manfaat meningkatkan kepercayaan diri dan kepuasan ibu, dukungan tenaga kesehatan juga dapat menambah wawasan dan pengetahuan ibu dalam keberhasilan ASI Eksklusif. Hal ini didukung dengan 3 artikel, yaitu A1, A3, A8 yang menjelaskan bahwa informasi yang baik dan benar dari tenaga kesehatan terkait keberhasilan ASI Eksklusif dapat menambah wawasan dan pengetahuan ibu. Sehingga untuk meningkatkan wawasan dan pengetahuan ibu agar selalu mendapatkan ilmu terbaru tenaga kesehatan perlu untuk mengikuti pelatihan yang berorientasi pada proses yang terintegrasi fakta dengan refleksi yang mengarah pada peningkatan mutu dan sikap profesional untuk mengembangkan keterampilan profesional tenaga kesehatan (Anette, et al. 2015). 


\section{Simpulan}

Menurut WHO di beberapa jurnal penelitian ASI Eksklusif menyatakan bahwa dukungan tenaga kesehatan dan juga keluarga sangat penting untuk memastikan keberhasilan dalam memberikan ASI eksklusif pada ibu yang menyusui. Menyusui eksklusif direkomendasikan sebagai sumber nutrisi terbaik untuk bayi dan merupakan masalah kesehatan masyarakat yang penting. Dukungan tenaga kesehatan adalah salah satu faktor yang terkait dengan pemberian ASI eksklusif pada ibu yang menyusui. Secara khusus, ibu yang menerima dukungan tenaga kesehatan yang memadai memiliki manfaat dalam meningkatkan kepercayaan diri dan kepuasan ibu serta dapat menambah wawasan dan pengetahuan ibu dalam ASI Eksklusif.

Studi ini telah memberikan review terkait outcome dukungan tenaga kesehatan dalam keberhasilan ASI Eksklusif di negara berkembang dan maju, namun peneliti menemukan adanya gaps dalam studi ini, diantaranya masih sedikitnya penelitian tentang program-program baru untuk meningkatkan keberhasilan ASI Eksklusif.

\section{Daftar Pustaka}

Abbass-Dick, J., Stern, S.B., Nelson, L.E., Watson, W., Dennis, C.-L., 2015. Coparenting breastfeeding support and exclusive breastfeeding: a randomized controlled trial. Pediatrics 135, 102-110. https://doi.org/10.1542/peds.2014-1416

Allen, J.A., Belay, B., Perrine, C.G., 2014a. Using mPINC data to measure breastfeeding support for hospital employees. J. Hum. Lact. Off. J. Int. Lact. Consult. Assoc. 30, 97-101. https://doi.org/10.1177/0890334413495974

Allen, J.A., Belay, B., Perrine, C.G., 2014b. Using mPINC data to measure breastfeeding support for hospital employees. J. Hum. Lact. Off. J. Int. Lact. Consult. Assoc. 30, 97-101. https://doi.org/10.1177/0890334413495974

Anstey, E.H., MacGowan, C.A., Allen, J.A., 2016. Five-Year Progress Update on the Surgeon General's Call to Action to Support Breastfeeding, 2011. J. Womens Health 2002 25, 768- 776. https://doi.org/10.1089/jwh.2016.5990
Arksey, H., \& Malley, L. O. (2005). SCOPING STUDIES: TOWARDS A METHODOLOGICAL FRAMEWORK. 19-32.

Astuti, A., Hirst, J., \& Bharj, K. (2019). Indonesian Adolescents' Experiences During Pregnancy and Early Parenthood: a Qualitative Study. Journal of Psychosomatic Obstetrics \& Gynecology.

https://doi.org/10.1080/0167482X.2019.169 3538

Cato, K., Sylvén, S.M., Lindbäck, J., Skalkidou, A., Rubertsson, C., 2017. Risk factors for exclusive breastfeeding lasting less than two months-Identifying women in need of targeted breastfeeding support. PloS One 12, e0179402.

https://doi.org/10.1371/journal.pone.017940 2

Claudine, M., Chi, N., Liamputtong, P., \& Mcmichael, C. (2015). Early motherhood: a qualitative study exploring the experiences of African Australian teenage mothers in greater Melbourne, Australia. BMC Public Health, 111. https://doi.org/10.1186/s12889-0152215-2

Copeland, R. J. (2017). Experiences of adolescent mothers in Costa Rica and the role of parental support. Journal of Family Social Work, 20(5), 416-432. https://doi.org/10.1080/10522158.2017.130 0114

Devito, J. (2007). How Adolescent Mothers Feel About Becoming a Parent. 25-34. https://doi.org/10.1624/105812410X495523

Erfina, E., Widyawati, W., McKenna, L., Reisenhofer, S., \& Ismail, D. (2019). Exploring Indonesian adolescent women's healthcare needs as they transition to motherhood: A qualitative study. Women and Birth, 32, 544551.

https://doi.org/10.1016/j.wombi.2019.02.00 7

Ganchimeg, T., Ota, E., Morisaki, N., Laopaiboon, M., Lumbiganon, P., \& Zhang, J. (2014). Pregnancy and childbirth outcomes among adolescent mothers: a World Health Organization multicountry study. 40-48. https://doi.org/10.1111/1471-0528.12630

Hauck, Y.L., Blixt, I., Hildingsson, I., Gallagher, L., Rubertsson, C., Thomson, B., Lewis, L., 2016. 
Australian, Irish and Swedish women's perceptions of what assisted them to breastfeed for six months: exploratory design using critical incident technique. BMC Public Health 16 , 1067. https://doi.org/10.1186/s12889-016-3740-3

Hunter, L., Magill-Cuerden, J., \& Mccourt, C. (2015). Disempowered, passive and isolated: How teenage mothers' postnatal inpatient experiences in the UK impact on the initiation and continuation of breastfeeding. Maternal and Child Nutrition, 11(1), 47-58. https://doi.org/10.1111/mcn.12150

Machado, M.C.M., Assis, K.F., Oliveira, F. de C.C., Ribeiro, A.Q., Araújo, R.M.A., Cury, A.F., Priore, S.E., Franceschini, S. do C.C., 2014. Determinants of the exclusive breastfeeding abandonment: psychosocial factors. Rev. Saude Publica 48, 985-994. https://doi.org/10.1590/S00348910.2014048005340

Mallette, J. K., Futris, T. G., Brown, G. L., \& Oshri, A. (2015). The Influence of Father Involvement and Interparental Relationship Quality on Adolescent Mothers' Maternal Identity. Family Relations, 64(4), 476-489. https://doi.org/10.1111/fare.12132
Mangeli, M., Sc, M., Rayyani, M., Ph, D., Cheraghi, M. A., \& Ph, D. (2017). Exploring the Challenges of Adolescent Mothers From Their Life Experiences in the Transition to Motherhood: A Qualitative Study. 11(3), 165-173.

Mohammadi, N., Montazeri, S., Alaghband rad, J., Ardabili, H. E., \& Gharacheh, M. (2016a). Iranian pregnant teenage women tell the story of "fast development": A phenomenological study. Women and Birth, 29(4), 303-309. https://doi.org/10.1016/j.wombi.2015.11.00 3

Mohammadi, N., Montazeri, S., Alaghband rad, J., Ardabili, H. E., \& Gharacheh, M. (2016b). Iranian pregnant teenage women tell the story of "fast development": A phenomenological study. Women and Birth, 29(4),

303-309. https://doi.org/10.1016/j.wombi.2015.11.00 3

Ngai, F., \& Chan, S. W. (2011). International Journal of Nursing Studies Psychosocial factors and maternal wellbeing: An exploratory path analysis. International Journal of Nursing Studies, 48(6), 725-731. https://doi.org/10.1016/j.ijnurstu.2010.11.00 2 